\title{
OBITUARY: D. E. L. Haynes
}

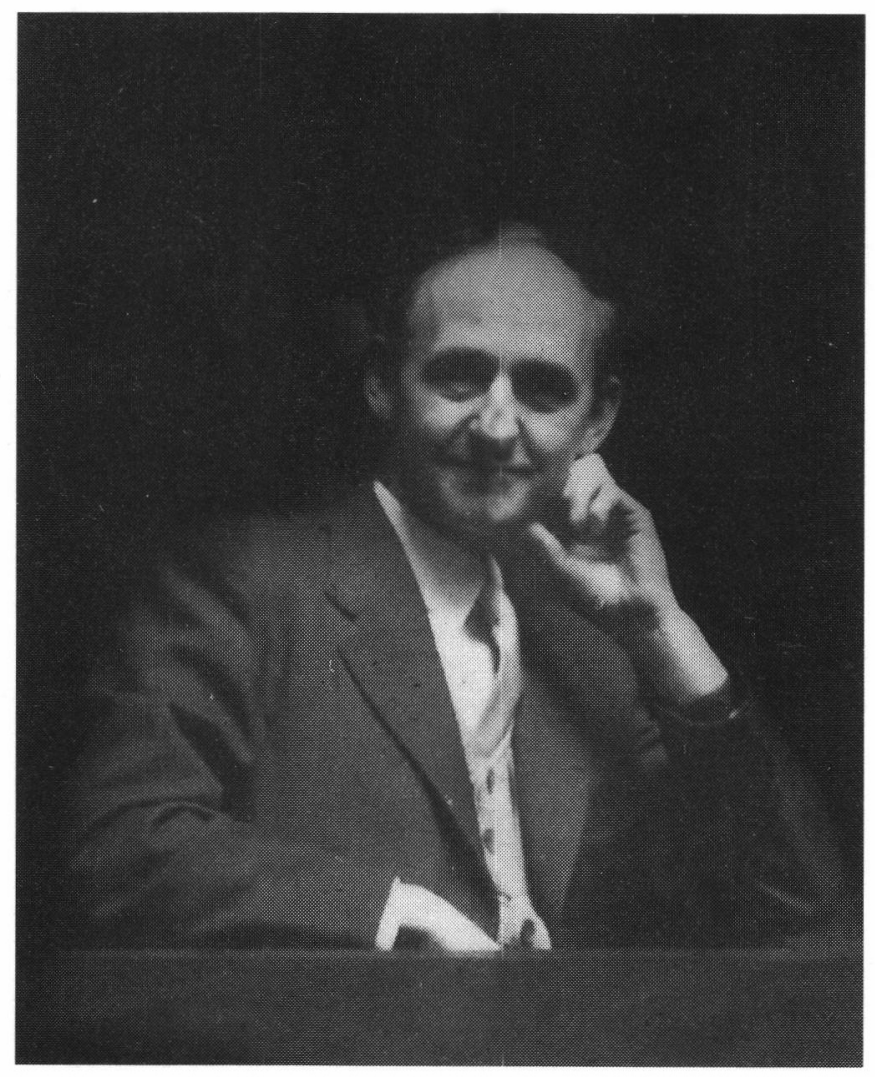

Denys Eyre Lankaster Haynes died at Oxford on the 27th of September 1994 at the age of 81. He was born on the 15th of February 1913 at Harrogate, and was educated at Marlborough, from where he went to Trinity College, Cambridge. After a year as a Scholar at the British School of Rome he was appointed to the post of Assistant Keeper in the Department of Metalwork in the Victoria and Albert Museum, where was aroused his lifelong interest in foundry techniques and the way that bronze figures were produced. After two years, in 1939, he went to the British Museum to serve with Bernard Ashmole, Keeper of Greek and Roman Antiquities and a fellow Assistant Keeper, Martin Robertson. Their main duties were far from academic as the imminent war made necessary the gigantic and complex task of packing and distributing the classical collections to safe storage, the Parthenon sculptures to Aldwych tube station, much of the more portable material to Compton Wynyates; others placed deep in the basements of the Museum.

This achieved, Haynes went to the War Office and worked in the Intelligence Service in Britain and later in Italy. Even during the war some thought was given to the protection of ancient sites in areas that were and had been battlefields, and in 1943 he was appointed Antiquities Officer for Libya, his brief being as far as possible 
to look after the ancient sites of that land, including the immense clearances and reconstructions carried out by pre-war Italian archaeologists. The British military presence remained in Libya for some time after the war was over, and the Department of Antiquities was headed for some time by Englishmen. Haynes wrote a guide, Ancient Tripolitania, published in 1946 (the same year that he returned to the British Museum) 'primarily for the military tourist'. The revised edition of 1956 and two corrected reprints of 1959 and 1965, now edited An Archaeological and Historical Guide to the Pre-Islamic Antiquities of Tripolitania, remains, despite 30 years of subsequent work, the best and most useful guide to the area, in English and probably any language.

He returned to the Museum to undertake, with very few colleagues, the immense task of bringing back the collections to Bloomsbury. Priority was given to the sculptures of the Parthenon. Ashmole disliked the Duveen Gallery, built just before the war to house them, and bomb damage to that gallery enabled him to place them where he wanted them, in the old Elgin Room and the two galleries to its north. It was left to Haynes, as Keeper of Greek and Roman Antiquities after Ashmole's departure to Oxford in 1956, to clear out the row upon row of spears stored there by the Department of Ethnography, and to organise the placement of the Parthenon sculptures in Duveen's tasteful, but overblown and not entirely suitable setting. On the upper floor, the necessities of circulation ensured that the Room of Daily Life, open to the sky since the bombing, was redesigned, and the Terracotta Room and the Vases Rooms (now regrettably gone) were reopened. But this was only the beginning of a major refurbishment of the entire run of the Department's ground floor galleries. Their sculptural monopoly ceased and minor antiquities were introduced to produce a chronological and cultural sequence of mainly Greek art and archaeology, from the Bronze Age through to the Hellenistic period. Sculpture did remain, in particular the Nereid Monument, with its restored facade built under the supervision of Donald Strong, and the Bassae Frieze occupying a room of its own. Ephesus was the main loser, the huge sculptured piers disappearing and only one drum remaining amidst the Mausoleum material. Although the upper floor galleries are recently much changed, and the ground floor has seen some alteration, the post-war exhibition was radically different from that pertaining before 1939. All this was done under Denys Haynes' direction, using time he would have rather spent on his academic work; he was upheld by the never-failing support of his wife Sybille, herself a scholar of note.

He did, however, produce works of importance and elegance: his search for the right way of putting things often caused him much anguish. His An Historical Guide to the Sculptures of the Parthenon was published in 1962 at the time the Duveen Gallery opened, and to the present writer's mind his interpretation of The Portland Vase (1964) remains the most satisfactory. The volume he wrote for presentation to the Queen when she opened the ground floor galleries in 1969, Fifty Masterpieces of Classical Art in the British Museum is a monument to his style. Many papers in learned journals showed his wide range of interests, and the discovery of pieces of the Great Altar of Pergamon in places like Worksop, but deriving ultimately from the seventeenthcentury collection of the Earl of Arundel, led to his most useful discussion of that collection and its rump in the Ashmolean Museum (The Arundel Marbles), published in 1975, a year before he retired from the British Museum. In 1981 he brought out his Greek Art and the Idea of Freedom and his major work, one to which his interests had always led, The Technique of Greek Bronze Statuary, appeared in 1982.

Denys Haynes was an efficient, kind and considerate Keeper of his Department, one with whom it was pleasant to work with and under. His readiness to accept extra responsibilities is illustrated by his taking on the Chairmanship of the Society of 


\section{OBITUARY}

Libyan Studies on the tragic death in 1973 of Donald Strong. The Secretary, Shirley Strong, can vouch for his effectiveness: letters that needed to be written were always produced the day following their discussion; he remained Chairman until 1975 . He will be remembered with affection.

Donald M. Bailey 